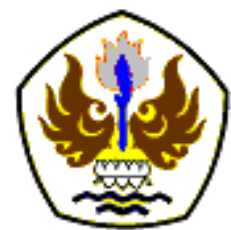

INFOMATEK

Volume 21 Nomor 1 Juni 2019

\title{
PENYISIHAN TOTAL COLIFORM DALAM AIR HUJAN MENGGUNAKAN MEDIA FILTER ZEOLITE TERMODIFIKASI, KARBON AKTIF, DAN MELT BLOWN FILTER CARTRIDGE
}

\author{
Lili Mulyatna, Astri Hasbiah ${ }^{\star}$, Widia Rahmawati Pahilda \\ Program Studi Teknik Lingkungan \\ Fakultas Teknik - Universitas Pasundan
}

\begin{abstract}
Abstrak: Indonesia dengan curah hujan sebesar 2.000-3.000 mm per tahun dapat memanfaatkan air hujan sebagai salah satu sumber air minum. Akan tetapi, sebelumdapat dimanfaatkan air hujan harus diolah terlebih dahulu karena air hujan yang di panen dari atap rumah biasanya terkontaminasi pencemar mikrobiologi. Organisme yang merupakan indikator pencemar mikrobiologi adalah coliform. Penelitian ini bertujuan untuk menyisihkan total coliform yang terdapat dalam air hujan.Penelitian dilakukan dengan menggunakan filtrasi media berbutir. Media filter yang digunakan yaitu Zeolite termodifikasi (TNZ) tipe RC.32 dan RC.42, karbon aktif, dan melt blown filter cartridge dengan ukuran 3 dan 1 mikrometer. Filtrasi dilakukan dengan menggunakan dua buah reaktor berukuran 10 dan 20 inch.Penelitian dilakukan dengan tiga variasi susunan media filter untuk mendapat susunan media filter yang paling optimal dalam menyisihkan total coliform. Filtrasi menggunakan susunan media TNZ RC.32-Cartridge granural karbon aktif-Melt blown flter cartridge 3 mikron dengan ukuran reaktor 20 inch merupakan susunan variasi media filter terbaik karena dapat menyisihkan $100 \%$ total coliform dari air hujan.
\end{abstract}

Kata kunci: Air Hujan, Filtrasi, Karbon Aktif, Melt Blown Filter Cartridge, Zeolite termodifikasi

\section{PENDAHULUAN}

Indonesia dengan curah hujan tahunan yang cuku tinggi sebesar 2.000-3.000 mm dapat memanfaatkan Air hujan sebagai salah satu sumber air baku air minum. Salah satu cara yang dapat digunakan adalah dengan pemanenan air hujan (Julius [1]). Akan tetapi, sebelum dapat dimanfaatkan air hujan harus diolah terlebih dahulu karena air hujan yang di

\footnotetext{
*) astrihasbiah@unpas.ac.id
}

Pertama diterima : 14 Januari 2019

Direvisi : 16 Mei 2019

Disetujui untuk publikasi: 20 Mei 2019 panen dari atap rumah biasanya terkontaminasi pencemar mikrobiologi yang berasal dari hewan atau akibat terbawa oleh angin (Sari dkk. [2]). Organisme yang merupakan indikator pencemar mikrobiologi adalah coliform di mana jumlah koloni coliform memiliki korelasi positif dengan keberadaan bakteri patogen. Pemeriksaaan terhadap keberadaan coliform sangat mudah dan relatif murahdibandingkan dengan mendeteksi jenis bakteri patogen lainnya. Oleh karena itu pemeriksaan total coliform banyak digunakan dalam pemeriksaan kualitas air. 
Filtrasi media berbutir merupakan salah satu metode pengolahan air karena mampu menyisihkan $87,86 \%$ total coliform dari air sumur (Yulianti [3]). Media filter yang banyak digunakan adalah zeolite, karbon aktif, dan melt blown filter cartridge. Penelitian ini bertujuan untuk menyisihkan total coliform dalam air hujan menggunakan filter zeolite termodifikasi, karbon aktif, dan melt blown filter cartridge.

\section{METODOLOGI}

Penelitian ini menggunakan 2 buah filter reaktor, satu buah drum plastik penampung air bervolume 160 liter dan satu pompa celup air bersih dengan daya listrik 80 watt dengan daya motor 220 volt-50 Hz. Media zeolite termodifikasi yang digunakan adalah tipe RC.32 dan RC. 42. Karbon aktif yang digunakan dikemas dalam cartridge berukuran 10 dan 20 inch. Melt blown filter cartridge yang digunakan berukuran 1 dan 3 mikrometer. Air hujan yang dikumpulkan merupakan air hujan setelah 10-20 menit durasi hujan, hal ini bertujuan untuk membilas atap bangunan dari pencemar.

Sebelum menghitung penyisihan terlebih dahulu dilakukan perhitungan debit inlet yaitu dengan cara membuka valve (katup) pada reaktor, kemudian menampung air yang mengalir dengan gelas kimia 1000 mL kemudian mencatat waktu yang dibutuhkan air untuk mengisi penuh gelas kimia tersebut. Kemudian dihitung dengan persamaan berikut:

$$
\mathrm{Q}=\mathrm{V} / \mathrm{t}
$$

Dimana:

Q = Debit aliran (Liter/detik)

$\mathrm{V}=$ Volume wadah yang digunakan untuk menampung air (1000 $\mathrm{mL}=1$ Liter $)$

$\mathrm{t}=$ waktu yang dibutukan air untuk mengisi gelas kimia tepat di $1000 \mathrm{~mL}$ (detik)

Sedangkan untuk menentukan kecepatan aliran air dalam reaktor dapat diketahui dengan menggunakan persamaan berikut:

$$
\mathrm{V}=\mathrm{Q} / \mathrm{A}
$$

Dimana:

$\mathrm{V}=$ Kecepatan air (m/detik)

$\mathrm{Q}=$ Debit aliran (m3/detik)

$A=$ Luas penampang $(1 / 4 \pi D 2)$

$\mathrm{D}=$ Diameter pipa yang digunakan pada reaktor, yaitu 0,5 inch $=0,0127 \mathrm{~m}$

Reaktor yang digunakan pada penelitian ini dapat dilihat pada Gambar 1 dan 2. Adapun komponen pada masing-masing reaktor sebagai berikut:

Reaktor 1 terdiri dari:

- 3 casing filter ukuran 10 inch

- 3 buah penutup casing filter

- 2 buah pipa outlet dengan panjang $26 \mathrm{~cm}$ dan berdiameter 0,5 inch

- 1 buah katup (valve) 
- Stainless steel sebagai Rangka reaktor dengan dimensi $84,5 \times 50 \times 50 \mathrm{~cm}$

- 4 buah keran

- 6 buah water inlet valve AC 220-240 Volt $50 / 60 \mathrm{~Hz}$

- 1 buah pengatur arah aliran.

Reaktor 2 terdiri dari:

- 3 casing filter ukuran 20 inch

- 3 buah penutup casing filter

- 2 buah pipa outlet dengan panjang $52 \mathrm{~cm}$ dan berdiameter 0,5 inch

- 1 buah katup (valve)

- Stainless steel sebagai Rangka reaktor dengan dimensi $84,5 \times 50 \times 73 \mathrm{~cm}$

- 4 buah keran

- 6 buah water inlet valve AC 220-240 Volt $50 / 60 \mathrm{~Hz}$ yang berfungsi sebagai pemutus aliran air ketika arah aliran diganti.

- 1 buah pengatur arah aliran

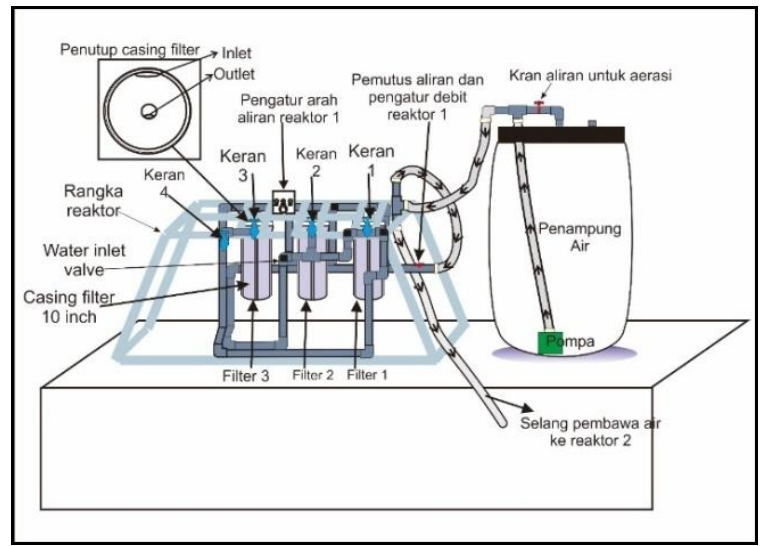

Gambar 1.

Reaktor 1

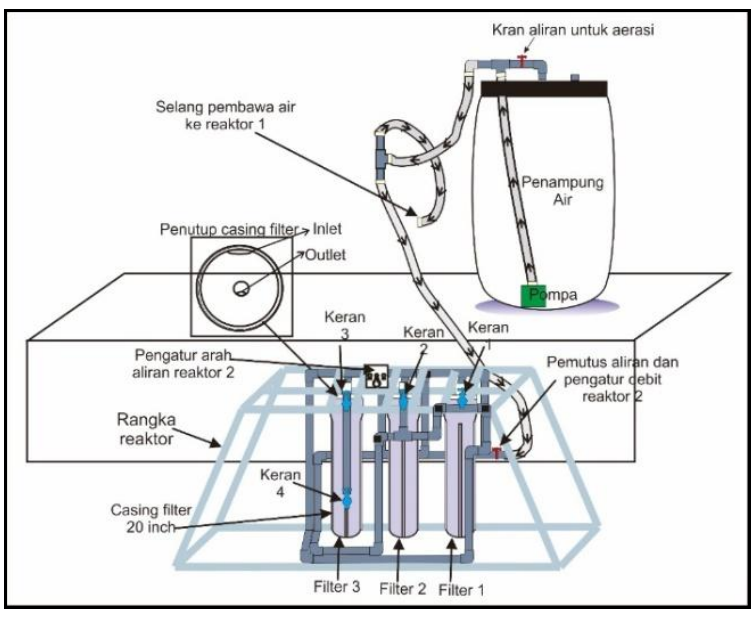

Gambar 2.

Reaktor 2

Detail dari casing filter dapat dilihat pada Gambar 3. Casing Filter digunakan sebagai wadah media filter dengan ukuran 20 inch dan 10 inch.

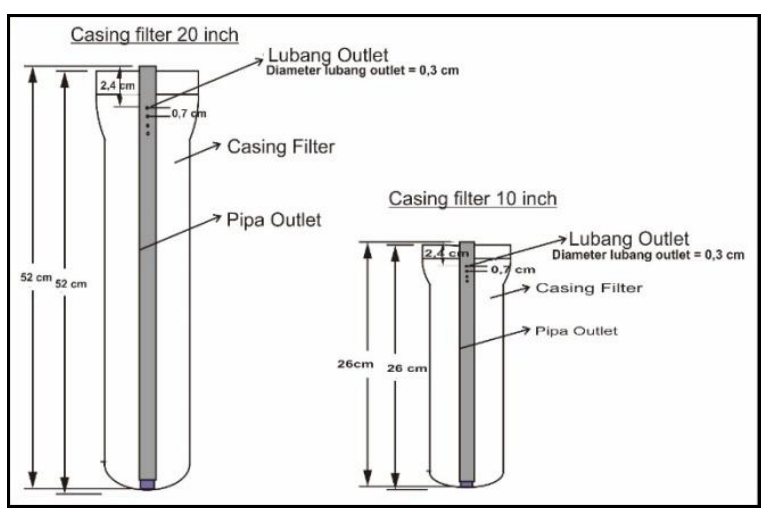

Gambar 3.

Detail Casing Filter

Arah aliran dalam kedua reaktor dapat diatur menjadi dua variasi arah aliran dengan pengatur aliran. Arah aliran setiap media filter dalam casing filter dapat dilihat pada Gambar 4. 


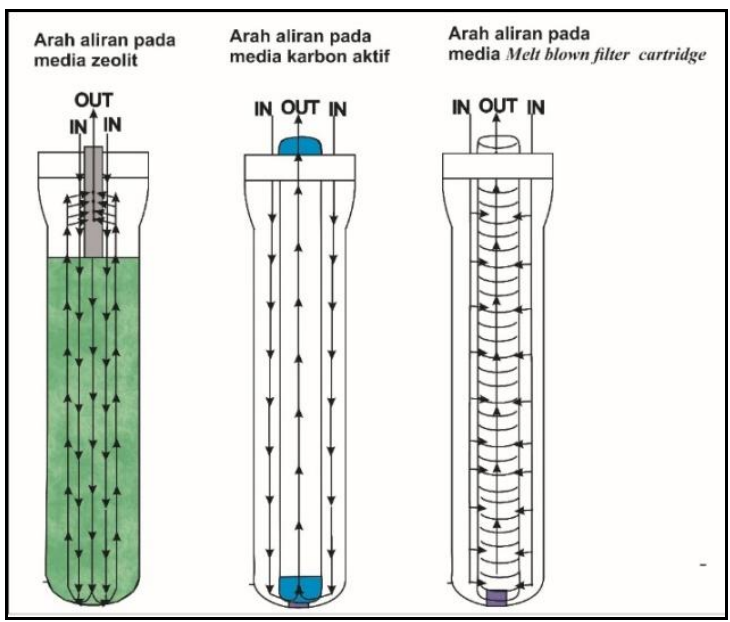

Gambar 4.

Arah Aliran Air dalam Casing Filter

Media filter yang digunakan dalam penelitian ini adalah:

1. Zeolite termodifikasi yang terdiri dari 2 jenis yaitu:

- TNZ RC.32 merupakan zeolit yang memiliki fungsi untuk mengurangi TDS, TSS, $\mathrm{CO}_{2}$, dan alkalinitas

- TNZ RC.42 merupakan zeolit yang memiliki fungsi untuk mengurangi kandungan $\mathrm{Fe}, \mathrm{Mn}$, bau, warna serta zat organik.

2. Cartridge granular karbon aktif ukuran 10 inch dan 20 inch, karbon aktif yang dikemas dalam cartridge ini memiliki fungsi untuk menghilangkan zat organik, bau, warna, dan rasa.

3. Cartridge filter yang terdiri dari:

- Melt blown filter cartridge 3 mikrometer 10 inch
- Melt blown filter cartridge 1 mikrometer 10 inch

- Melt blown filter cartridge 3 mikrometer 20 inch

- Melt blown filter cartridge 1 mikrometer 20 inch

Cartridge filter ini memiliki fungsi mengurangi kandungan lumpur, pasir, yang merupakan penyebab kekeruhan. Pemilihan melt blown filter cartridge ukuran 3 mikrometer dan 1 mikrometer dikarenakan ukuran tersebut banyak digunakan dalam pengolahan air minum, misalnya untuk air minum isi ulang.

Variasi susunan media filter yang digunakan adalah:

1. TNZ RC.42- TNZ RC.32-Cartidge granular karbon aktif,

2. TNZ RC.32-Cartidge granular karbon aktif-Melt Blown Fiter Cartridge 3 mikrometer

3. Cartidge granular karbon aktif-Melt Blown Filter Cartridge 3 mikrometerMelt Blown Fiter Cartridge 1 mikrometer.

Metode yang digunakan dalam pemeriksaan coliform pada penelitian ini adalah metode penyaringan membran. Sampel air disaring dengan kertas membran filter 0,45 mikrometer dan diberi media Endo Agar kemudian diinkubasi. Koloni yang tumbuh kemudian 
dihitung jumlahnya menggunakan koloni counter.

Analisa data yang dilakukan yaitu membandingkan pengaruh dari tiap variasi terhadap adanya peningkatan/ penurunan dari parameter uji (total coliform). Variasi terpilih merupakan variasi yang memiliki efisiensi penurunan terbesar. Efisiensi dapat dihitung dengan membandingkan influent dan effluent yang dinyatakan dalam persen (MetCalf dkk. [4]).

$$
\mathrm{E}=\frac{\text { Cawal }- \text { C akhir }}{\text { C awal }} \times 100 \%
$$

Dimana:

$$
\begin{array}{ll}
\mathrm{E} & =\text { Efisiensi } \\
\mathrm{C} & =\text { Konsentrasi }
\end{array}
$$

\section{ANALISIS DAN PEMBAHASAN}

Dari hasil pemeriksaan kualitas air hujan awal menunjukkan nilai total coliform melebihi baku mutu Permenkes RI No. 492/Menkes/Per/ IV/2010. Hasil pengujian kualitas air hujan

\begin{tabular}{|c|c|c|c|c|c|c|c|}
\hline \multirow{2}{*}{ No } & \multirow{2}{*}{ Parameter } & \multirow{2}{*}{ Satuan } & \multirow{2}{*}{$\begin{array}{l}\text { Baku } \\
\text { Mutu* }\end{array}$} & \multicolumn{4}{|c|}{ Hasil analisis } \\
\hline & & & & 1 & 2 & 3 & Rata-rata \\
\hline \multicolumn{8}{|c|}{ Fisika } \\
\hline 1 & Kekeruhan & NTU & 5 & $8,84^{* *}$ & $8,80^{\star *}$ & $8,80^{\star *}$ & $8,81^{* *}$ \\
\hline 2 & TDS & $\mathrm{mg} / \mathrm{L}$ & 500 & 24 & 23 & 23 & 23,33 \\
\hline \multicolumn{8}{|c|}{ Kimia } \\
\hline 3 & $\mathrm{pH}$ & - & $6,5-8,5$ & $6,10^{* *}$ & $6,10^{\text {** }}$ & $5,58^{* *}$ & $6,06^{* *}$ \\
\hline 4 & Zat Organik & $\mathrm{mg} / \mathrm{L}$ & 10 & $24,94^{\star *}$ & $24,21^{* *}$ & $24,94^{\star *}$ & $24,70^{* *}$ \\
\hline \multicolumn{8}{|c|}{ Biologi } \\
\hline 5 & $\begin{array}{l}\text { Total } \\
\text { Coliform }\end{array}$ & $\mathrm{CFU} / 100 \mathrm{ml}$ & 0 & $98^{* *}$ & $87^{\star *}$ & $91^{* *}$ & $2,00^{* *}$ \\
\hline
\end{tabular}
awal dapat dilihat pada Tabel 1.

Tabel 1. Kualitas Air Hujan Awal

Pada penelitian ini debit dan kecepatan terbaik ditentukan dengan susunan media filter TNZ RC.32-TNZ RC.42-Cartridge granular karbon aktif karena berdasarkan penelitian Mulyatna dkk (2017) susunan filter ini mampu menurunkan kekeruhan, TDS, dan zat organik dalam air hujan (Mulyatna dkk. [5]). Pengukuran dari debit dan kecepatan yang didapatkan dapat dilihat pada Tabel 2. 
Tabel 2. Nilai Debit Inlet dan Kecepatan Aliran

\begin{tabular}{|c|c|c|c|c|c|c|c|}
\hline \multirow[t]{2}{*}{ No } & \multirow[t]{2}{*}{ Perlakuan } & \multicolumn{2}{|c|}{$\begin{array}{c}\text { Waktu mengisi } \\
\text { penuh gelas kimia } \\
1000 \mathrm{ml} \\
\text { (detik) }\end{array}$} & \multicolumn{2}{|c|}{$\begin{array}{c}\text { Debit } \\
\text { (Liter/detik) }\end{array}$} & \multicolumn{2}{|c|}{$\begin{array}{c}\text { Kecepatan } \\
\text { (m/detik) }\end{array}$} \\
\hline & & $\begin{array}{c}\text { Reaktor } \\
1\end{array}$ & $\begin{array}{c}\text { Reaktor } \\
2\end{array}$ & $\begin{array}{c}\text { Reaktor } \\
1\end{array}$ & $\begin{array}{c}\text { Reaktor } \\
2\end{array}$ & $\begin{array}{c}\text { Reaktor } \\
1\end{array}$ & $\begin{array}{c}\text { Reaktor } \\
2\end{array}$ \\
\hline 1 & Katup dibuka penuh & 7,9 & 7,2 & 0,1266 & 0,1389 & 0,9998 & 1,0970 \\
\hline 2 & Katup dibuka $1 / 2$ & 23,19 & 22,41 & 0,0431 & 0,0446 & 0,3406 & 0,3524 \\
\hline 3 & Katup dibuka $1 / 4$ & 68,11 & 67,23 & 0,0147 & 0,0149 & 0,1160 & 0,1175 \\
\hline
\end{tabular}

Semakin kecil nilai debit dan kecepatan menyebabkan semakin tinggi penyisihan parameter uji. Hal ini disebabkan karena semakin kecil debit maka semakin lama waktu yang dibutuhkan untuk proses filtrasi. Selain itu semakin besar debit dan kecepatan semakin banyak partikel halus dari media filter ikut terbawa aliran air. Debit dan kecepatan yang terlalu besar akan menyebabkan tidak berfungsinya filter secara efisien. Dengan adanya aliran yang terlalu cepat dalam melewati ruang pori di antara butiran media akan menyababkan berkurangnya waktu kontak antara permukaan butiran media (Sasmitha [6]). Waktu ideal untuk filtrasi menggunakan media TNZ yaitu 3 menit (180 detik).

\subsection{Variasi 1 dengan susunan media TNZ RC.42-TNZ RC.32- CartridgeGranular Karbon Aktif}

Hasil pemeriksaan total coliformhasil pengolahan oleh reaktor 1 dengan variasi 1 dapat dilihat pada Tabel 3 sedangkan hasil pada reaktor 2 dapat dilihat pada Tabel 4 .

Tabel 3. Efisiensi Penyisihan Total Coliform variasi 1 Pada Reaktor 1

\begin{tabular}{|c|c|c|c|c|c|c|}
\hline \multirow[b]{2}{*}{ No. } & \multirow[b]{2}{*}{ Media Filter } & \multicolumn{3}{|c|}{$\begin{array}{l}\text { Total Coliform } \\
\text { (CFU/100 mL) }\end{array}$} & \multirow[b]{2}{*}{$\begin{array}{c}\text { Rata-rata } \\
\text { (CFU/100 mL) }\end{array}$} & \multirow[b]{2}{*}{$\begin{array}{c}\text { Efisiensi } \\
\text { Penyisihan (\%) }\end{array}$} \\
\hline & & $\begin{array}{c}1 \\
\text { Data } \\
\text { Pengamatan: } \\
\text { 25 Januari } \\
2016 \\
\end{array}$ & $\begin{array}{c}2 \\
\text { Data } \\
\text { Pengamatan: } \\
26 \text { Januari } \\
2017 \\
\end{array}$ & $\begin{array}{c}3 \\
\text { Data } \\
\text { Pengamatan: } \\
27 \text { Januari } \\
2017 \\
\end{array}$ & & \\
\hline 1 & Air baku & $22^{* *}$ & $32^{* *}$ & $22^{\star \star}$ & $25,33^{\star *}$ & \\
\hline 2 & TNZ RC.42 & 0 & 0 & 0 & 0,00 & 100,00 \\
\hline 3 & TNZ RC.32 & 0 & 0 & 0 & 0,00 & 100,00 \\
\hline 4 & $\begin{array}{l}\text { Cartridgegranular } \\
\text { karbon aktif } 10 \text { inch }\end{array}$ & 0 & 0 & 0 & 0,00 & 100,00 \\
\hline
\end{tabular}


Tabel 4. Efisiensi Penyisihan Total Coliform variasi 1 Pada Reaktor 2

\begin{tabular}{|c|c|c|c|c|c|c|}
\hline \multirow[b]{2}{*}{ No. } & \multirow[b]{2}{*}{ Media Filter } & \multicolumn{3}{|c|}{$\begin{array}{l}\text { Total Coliform } \\
\text { (CFU/100 mL) }\end{array}$} & \multirow[b]{2}{*}{$\begin{array}{l}\text { Rata-rata } \\
\text { (CFU/100 mL) }\end{array}$} & \multirow[b]{2}{*}{$\begin{array}{l}\text { Efisiensi } \\
\text { Penyisihan (\%) }\end{array}$} \\
\hline & & $\begin{array}{c}1 \\
\text { Data } \\
\text { Pengamatan: } \\
6 \text { Februari } \\
2017 \\
\end{array}$ & $\begin{array}{c}2 \\
\text { Data } \\
\text { Pengamatan: } \\
\text { 8 Februari } \\
2017 \\
\end{array}$ & $\begin{array}{c}3 \\
\text { Data } \\
\text { Pengamatan: } \\
9 \text { Februari } \\
2017 \\
\end{array}$ & & \\
\hline 1 & Air baku & $27^{* *}$ & $39^{* *}$ & $22^{\star *}$ & $29,33^{* *}$ & \\
\hline 2 & TNZ RC.42 & 0 & 0 & 0 & 0,00 & 100,00 \\
\hline 3 & TNZ RC.32 & 0 & 0 & 0 & 0,00 & 100,00 \\
\hline 4 & $\begin{array}{l}\text { Cartridgegranular } \\
\text { karbon aktif } 20 \text { inch }\end{array}$ & 0 & 0 & 0 & 0,00 & 100,00 \\
\hline
\end{tabular}

Dari hasil pemeriksaan total coliform dengan variasi TNZ RC.42-TNZ RC.32-Cartridge granular karbon aktif baik pada reaktor 1 maupun reaktor 2 menunjukkan bahwa penyaringan dengan menggunakan media filter TNZ RC.42 saja sudah dapat menyisihkan total coliform dari air hujan sampai dengan 100\%. Penyisihan total coliform pada TNZ RC.42 ini disebabkan oleh ukuran pori media TNZ yang berukuran $10^{-7}$. $10^{-9} \mathrm{~mm}$. Sedangkan bakteri coliform sendiri memiliki ukuran 0,0005-0,003 $\mathrm{mm}$. Pada dasarnya bakteri dapat tersaring jika ukuran filter jauh lebih kecil dari pada ukuran bakteri tersebut (Yuliawati [7]).

\subsection{Variasi 2 dengan susunan media TNZ} RC.32 -Cartridge Granular Karbon AktifMelt Blown Filter Cartridge 3 mikrometer

Hasil pemeriksaan total coliform hasil pengolahan oleh reaktor 1 dengan variasi 2 dapat dilihat pada Tabel 5 sedangkan hasil pada reaktor 2 dapat dilihat pada Tabel 6 .

Tabel 5. Efisiensi Penyisihan Total Coliform variasi 2 Pada Reaktor 1

\begin{tabular}{|c|c|c|c|c|c|c|}
\hline \multirow[b]{2}{*}{ No. } & \multirow[b]{2}{*}{ Media Filter } & \multicolumn{3}{|c|}{$\begin{array}{l}\text { Total Coliform } \\
\text { (CFU/100 mL) }\end{array}$} & \multirow[b]{2}{*}{$\begin{array}{c}\text { Rata-rata } \\
\text { (CFU/100 mL) }\end{array}$} & \multirow[b]{2}{*}{$\begin{array}{c}\text { Efisiensi } \\
\text { Penyisihan } \\
(\%)\end{array}$} \\
\hline & & $\begin{array}{c}1 \\
\text { Data } \\
\text { Pengamatan: } \\
\text { 10 Februari } \\
2017 \\
\end{array}$ & $\begin{array}{c}2 \\
\text { Data } \\
\text { Pengamatan: } \\
11 \text { Februari } \\
2017 \\
\end{array}$ & $\begin{array}{c}3 \\
\text { Data } \\
\text { Pengamatan: } \\
\text { 15 Februari } \\
2017 \\
\end{array}$ & & \\
\hline 1 & Air Baku & $113^{\star *}$ & $11^{* *}$ & $29^{* *}$ & $51,00^{* *}$ & \\
\hline 2 & TNZ RC.32 & 0 & 0 & 0 & 0,00 & 100,00 \\
\hline 3 & $\begin{array}{l}\text { Cartridge granular } \\
\text { karbon aktif } 10 \text { inch }\end{array}$ & 0 & 0 & 0 & 0,00 & 100,00 \\
\hline 4 & $\begin{array}{l}\text { Melt blown filter } \\
\text { cartridge } \\
\text { mikrometer } 10 \text { inch }\end{array}$ & 0 & 0 & 0 & 0,00 & 100,00 \\
\hline
\end{tabular}


Tabel 6. Efisiensi Penyisihan Total Coliform variasi 2 Pada Reaktor 2

\begin{tabular}{|c|c|c|c|c|c|c|}
\hline \multirow[b]{2}{*}{ No. } & \multirow[b]{2}{*}{ Media Filter } & \multicolumn{3}{|c|}{$\begin{array}{l}\text { Total Coliform } \\
\text { (CFU/100 mL) }\end{array}$} & \multirow[b]{2}{*}{$\begin{array}{c}\text { Rata-rata } \\
\text { (CFU/100 mL) }\end{array}$} & \multirow[b]{2}{*}{$\begin{array}{c}\text { Efisiensi } \\
\text { Penyisihan (\%) }\end{array}$} \\
\hline & & $\begin{array}{c}1 \\
\text { Data } \\
\text { Pengamatan: } \\
\text { 23 Februari } \\
2017 \\
\end{array}$ & $\begin{array}{c}2 \\
\text { Data } \\
\text { Pengamatan: } \\
2 \text { Maret 2017 }\end{array}$ & $\begin{array}{c}3 \\
\text { Data } \\
\text { Pengamatan: } \\
3 \text { Maret } 2017\end{array}$ & & \\
\hline 1 & Air Baku & $68^{* *}$ & $64^{\star *}$ & $23^{\star *}$ & $51,67^{\star *}$ & \\
\hline 2 & TNZ RC.32 & 0 & 0 & 0 & 0,00 & 100,00 \\
\hline 3 & $\begin{array}{l}\text { Cartridge granular karbon } \\
\text { aktif } 20 \text { inch }\end{array}$ & 0 & 0 & 0 & 0,00 & 100,00 \\
\hline 4 & $\begin{array}{l}\text { Melt blown filter cartridge } 3 \\
\text { mikrometer } 20 \text { inch }\end{array}$ & 0 & 0 & 0 & 0,00 & 100,00 \\
\hline
\end{tabular}

Keterangan:

${ }^{* * M e l e b i h i ~ B a k u ~ M u t u}$

Dari hasil pemeriksaan total coliform dengan variasi TNZ RC.32-Cartridge granular karbon aktif-Melt blown filter cartridge 3 mikrometer baik pada reaktor 1 maupun reaktor 2 menunjukkan bahwa penyaringan pada media TNZ RC. 32 saja sudah dapat menyisihkan kandungan bakteri coliform dari air hujan sebesar $100 \%$. Hasil ini sama dengan variasi dengan media TNZ RC.32-TNZ RC.42Cartridge granular karbon aktif. Tidak ada peningkatan total coliform yang terjadi walaupun hanya digunakan 1 tipe media TNZ saja. Dapat dilihat pada media karbon aktif hasil pemeriksaan total coliform juga menunjukkan hasil negatif, begitu pula pada melt blown filter cartridge 3 mikrometer.

\subsection{Variasi 3 dengan susunan} mediaCartridge Granural Karbon Aktif-Melt Blown Filter Cartridge 3 mikrometer- Melt Blown Filter Cartridge 1 mikrometer

Hasil pemeriksaan total coliformhasil pengolahan dari variasi 3 dengan filtrasi oleh reaktor 1 dapat dilihat pada Tabel 7 sedangkan hasil reaktor 2 dapat dilihat pada Tabel 8.

Tabel 7. Efisiensi Penyisihan Total Coliform variasi 3 Pada Reaktor 1

\begin{tabular}{|c|c|c|c|c|c|c|}
\hline \multirow[b]{2}{*}{ No. } & \multirow[b]{2}{*}{ Media Filter } & \multicolumn{3}{|c|}{$\begin{array}{l}\text { Total Coliform } \\
\text { (CFU/100 mL) }\end{array}$} & \multirow[b]{2}{*}{$\begin{array}{l}\text { Rata-rata } \\
\text { (CFU/100 mL) }\end{array}$} & \multirow[b]{2}{*}{$\begin{array}{l}\text { Efisiensi } \\
\text { Penyisihan (\%) }\end{array}$} \\
\hline & & $\begin{array}{c}1 \\
\text { Data } \\
\text { Pengamatan: } \\
8 \text { Maret } 2017\end{array}$ & $\begin{array}{c}\mathbf{2} \\
\text { Data } \\
\text { Pengamatan: } \\
9 \text { Maret } 2017\end{array}$ & $\begin{array}{c}\mathbf{3} \\
\text { Data } \\
\text { Pengamatan: } \\
\text { 12 Maret } 2017\end{array}$ & & \\
\hline 1 & Air Baku & $108^{* *}$ & $20^{* *}$ & $34^{* *}$ & $53,89^{* *}$ & \\
\hline 2 & $\begin{array}{l}\text { Cartridge granular karbon } \\
\text { aktif } 10 \text { inch }\end{array}$ & $29 * *$ & $10^{* *}$ & $8^{* *}$ & $15,67^{\star *}$ & 70,93 \\
\hline 3 & $\begin{array}{l}\text { Melt blown filter cartridge } \\
3 \text { mikrometer } 10 \text { inch }\end{array}$ & $5^{\star *}$ & $2^{\star *}$ & $3^{* *}$ & $3,33^{* *}$ & 78,72 \\
\hline 4 & $\begin{array}{l}\text { Melt blown filter cartridge } \\
1 \text { mikrometer } 10 \text { inch }\end{array}$ & $2^{\star \star}$ & 0 & 0 & $0,67^{\star *}$ & 80,00 \\
\hline
\end{tabular}


Dari hasil pemeriksaan total coliform dengan variasiCartridge granular karbon aktif-Melt blown filter cartridge 3 mikrometer-Melt blown filter cartridge 1 mikrometer pada reaktor 1 didapatkan penyisihan total coliform sebesar 70,93\% pada media karbon aktif. Pada media karbon aktif total coliform yang semula berjumlah 53,89 CFU/ $100 \mathrm{~mL}$ dapat disisihkan menjadi 15,67 CFU/ $100 \mathrm{~mL}$, hal ini disebabkan karena proses adsorpsi fisik oleh media karbon aktif dimana bakteri terikat dengan lemah pada permukaan adsorben (Selamet, [8]). Terikat lemah karena ketika kesetimbangan adsorpsi telah tercapai namun proses adsorpsi masih berlangsung, adsorben menjadi jenuh dan akan melepaskan kembali sejumlah sel bakteri ke air.
Pada penelitian ini sampel air hasil penyaringan diambil seketika saat proses filtrasi dalam reaktor selesai (mengisi ketiga filter) jadi mungkin saja karbon aktif masih belum jenuh, sehingga terjadi penyisihan.

Pada penyaringan dengan melt blown filter cartridge 3 dan 1 mikrometer juga terjadi penurunan total coliform, hal ini dikarenakan media filter yang berukuran 3 dan 1 mikrometer. Diketahui bakteri coliform memiliki ukuran 0,5-3 mikrometer. Pada melt blown filter cartridge mungkin saja coliform menempel pada lapisan serat filter. Cartridge filter ini terbuat dari polypropylene (Kanade [9]).

Tabel 8. Efisiensi Penyisihan Total Coliform variasi 3 Pada Reaktor 2

\begin{tabular}{|c|c|c|c|c|c|c|}
\hline \multirow[b]{2}{*}{ No. } & \multirow[b]{2}{*}{ Media Filter } & \multicolumn{3}{|c|}{$\begin{array}{l}\text { Total Coliform } \\
\text { (CFU/100 mL) }\end{array}$} & \multirow[b]{2}{*}{$\begin{array}{l}\text { Rata-rata } \\
\text { (CFU/100 } \\
\text { mL) }\end{array}$} & \multirow[b]{2}{*}{$\begin{array}{l}\text { Efisiensi } \\
\text { Penyisihan } \\
(\%)\end{array}$} \\
\hline & & $\begin{array}{c}1 \\
\text { Data } \\
\text { Pengamatan: } \\
14 \text { Maret } \\
2017\end{array}$ & $\begin{array}{c}\mathbf{2} \\
\text { Data } \\
\text { Pengamatan: } \\
\text { 15 Maret } \\
2017 \\
\end{array}$ & $\begin{array}{c}3 \\
\text { Data } \\
\text { Pengamatan: } \\
17 \text { Maret } \\
2017\end{array}$ & & \\
\hline 1 & Air Baku & $108^{* *}$ & $27^{\star \star}$ & $43^{* *}$ & 59,53 & \\
\hline 2 & $\begin{array}{l}\text { Cartridge granular } \\
\text { karbon aktif } 20 \text { inch }\end{array}$ & $10^{* *}$ & 6 & 8 & 8,00 & 86,52 \\
\hline 3 & $\begin{array}{lr}\text { Melt blown filter } \\
\text { cartridge } \\
\text { mikrometer } 20 \text { inch }\end{array}$ & 0 & 0 & 0 & 0,00 & 100,00 \\
\hline 4 & $\begin{array}{lr}\text { Melt blown filter } \\
\text { cartridge } \\
\text { mikrometer } 20 \text { inch }\end{array}$ & 0 & 0 & 0 & 0,00 & 100,00 \\
\hline
\end{tabular}

Dari hasil pemeriksaan total coliform dengan variasiCartridge granular karbon aktif-Melt blown filter cartridge 3 mikrometer-Melt blown filter cartridge 1 mikrometer pada reaktor 2 didapatkan penyisihan total coliform sebesar $86,52 \%$ pada media karbon aktif. Total 
coliform yang semula 59,53 CFU/ $100 \mathrm{~mL}$ tersisihkan menjadi $8 \mathrm{CFU} / 100 \mathrm{~mL}$ oleh media karbon aktif. Penurunan total coliform yang terjadi lebih besar jika dibandingkan dengan penyisihan total coliform oleh media karbon aktif pada reaktor 1, hal ini dapat disebabkan karena media karbon aktif yang lebih tebal, di mana permukaan adsorben (karbon aktif) tempat bakteri menempel menjadi lebih luas. Sama halnya pada penyaringan dengan melt blown filter cartridge 3 mikrometer pada reaktor 2, karena melt blown filter cartridge lebih tebal sehingga penyisihan bakteri lebih besar yaitu menjadi 0 $\mathrm{CFU} / \mathrm{mL}$

Dari hasil penelitian menunjukkan karbon aktif belum mampu menyisihkan total coliform sampai dengan 0 (nol) seperti pada penyaringan menggunakan media zeolit. Hal ini dikarenakan jenis pori-pori dari karbon aktif yang lebih besar dari zeolit. Karbon aktif tergolong dalam makropori (> 50 nanometer atau >0,05 mikrometer) (Nugroho dkk [10]).

\section{KESIMPULAN}

Setelah dilakukan penelitian tentang pengolahan air hujan menggunakan reaktor dengan media filter Treated Natural Zeolite, karbon aktif, dan melt blown filter cartridge maka didapatkan kesimpulkan sebagai berikut:

1. Semakin kecil debit dan kecepatan maka semakin besar penyisihan kekeruhan, TDS, zat organik, total coliform, dan perbaikan $\mathrm{pH}$ yang terjadi.

2. Susunan media filter TNZ RC.32-Melt blown filter cartridge 3 mikrometerMelt blown filter cartridge 1 mikrometer pada reaktor dengan casing filter 20 inch merupakan variasi yang menyisihkan kekeruhan dan TDS terbesar yaitu 99,75\% untuk kekeruhan dan 22,22\% untuk TDS.

3. Susunan media filter TNZ RC.32-TNZ RC.42-Cartridge granular karbon aktif pada reaktor dengan casing filter 20 inch merupakan variasi yang menyisihkan zat organik terbesar yaitu $68,30 \%$.

4. Semua susunan media filter baik pada reaktor dengan casing filter 10 maupun 20 inch dapat digunakan dalam penyisihan total coliform karena efisiensi total coliform yang tersisihkan sebesar $98,14 \%-100 \%$.

5. Susunan media filter TNZ RC.32Cartridge granural karbon aktif-Melt blown flter cartridge 3 mikron menggunakan reaktor dengan casing 
filter 20 inch menjadi variasi yang terpilih karena memiliki efisiensi penurunan kekeruhan dan TDS terbesar serta mampu menyisihkan $59,95 \%$ zat organik dan $100 \%$ total coliform dari air hujan.

\section{DAFTAR PUSTAKA}

[1] Julius, R J., Prabhavathy, A., Ravikumar G.. "Rainwater Harvesting (RHW)-A Review". The International Journal of Innovative Research and Development, vol. 2, issue 5, pp. 925-937, 2013.

[2] Sari, I P. "Uji Bakteriologis Air Olahan Rainwater Harvesting System di SDN Pejagalan 01 dan 02, Jakarta Utara”. Damianus Journal of Medicine, vol. 14, no. 1, pp. 19-27. 2015

[3] Yulianti, D., Muflihah. A., Tien. Y. "Pengaruh Umur Pemakaian Zeolit Alam dan Arang dalam Penyaringan Air Sumur Sistem Adsorpsi Terhadap Kualitas Bakteriologis Air". Jurnal Prodi Biologi, vol 2, No 2, pp. 1-6. 2016

[4] Metcalf dan Eddy. Wastewater Engineering Treatment: Disposal and Reuse. $3^{\text {rd }}$ Edition. New York: McGraw-Hill Publisher, 1991.

[5] Mulyatna, L., Yustiani, Y.M., Hasbiah, A., Yopita, W. "Rainwater Treatment Using
Treated Natural Zeolite and Activated Carbon Filter". Proceeding The 1st IBSC: Towards The Extended Use Of Basic Science For Enhancing Health, Environment, Energy And Biotechnology, pp. 279-281, 2017.

[6] Sasmitha, D. Pemanfaatan Sampah Plastik Polyethylene Terephthalate (PET) Sebagai Media Pada Unit Pre-Filter. Skripsi. Surabaya: Jurusan Teknik Lingkungan Institut Teknologi Sepuluh September. 2017

[7] Yuliawati, R., Zarkowi Ahmad. "Sistem Operasional Damiu Dan Kualitas Bakteri Coliform Air Minum Isi Ulang di Perumahan Bumi Sempaja Wilayah Kerja Puskesmas Sempaja Tahun 2011". Artikel Ilmiah. Stikes Muda Samarinda, 2011.

[8] Selamet. R., Filosofi, R., Tristantini, D. "Disinfeksi Bakteri E.Coli Secara Fotokatalitik dengan Katalis Komposit Tio2Karbon Aktif Berpenyangga Batu Apung". Artikel Ilmiah Departemen Teknik Kimia, Fakultas Teknik, Universitas Indonesia, Jakarta. 2009

[9] Kanade, P.S. "Disposable Filters-A Review". International Journal Of Innovation Research in Science, Engineering and Technology, vol. 2, issue 10, pp. 5774-5779, 2013. 
Infomatek Volume 21 Nomor 1 Juni 2019 : 15 - 26

[10] Nugroho, W., Purwoto, S. "Removal Klorida, TDS dan Besi Pada Air Payau Melalui Penukar Ion dan Filtrasi Campuran Zeolit Aktif Dengan Karbon Aktif”. Jurnal Teknik Waktu, vol. 11, nomor 01, pp. 4759. 2013. 